Original Research Paper

\title{
Conservation Status of Bird Species on Promasan Hiking Trail, Mount Ungaran, Central Java
}

\author{
Arifah Purnamaningrum ${ }^{1 *}$, Moh Kafa Bihi ${ }^{1}$, Anif Risqianti Harits ${ }^{1}$ \\ ${ }^{1}$ Faculty of Science and Technology, UIN Walisongo Semarang, Semarang, Indonesia
}

\author{
Article History \\ Received : July $28^{\text {th }}, 2021$ \\ Revised : August $16^{\text {th }}, 2021$ \\ Accepted : September 02 $2^{\text {th }}, 2021$ \\ Published : September $13^{\text {th }}, 2021$ \\ *Corresponding Author: \\ Arifah Purnamaningrum, \\ Faculty of Science and Technology, \\ UIN Waslisongo Semarang, \\ Indonesia \\ Email: \\ purnamaningrum@walisongo.ac.id
}

\begin{abstract}
Mount Ungaran is one of the dormant volcanoes in Central Java. The condition of the unspoiled forest in the Mount Ungaran area is a good habitat for fauna, including birds. There are several hiking trails traversed by mountain climbers, one of them is the Promasan hiking trail. This study aims to determine the diversity of bird species and identify their conservation status on the Promasan hiking trail. Data were colected by Indices Ponctuels d'Abondance (IPA), Line Transect, and Point Count methods. Bird species diversity was determined by the Shanon index. Determination of bird conservation status based on the IUCN Red List, CITES Appendix, Government Regulation (PP No. 7 of 1999) and Ministry of Environment and Forestry Regulation (PERMENLHK RI No. 106, 2018). The results showed that there were 24 bird species belonging to 19 families. The diversity of bird species was classified as moderate (Shanon index $=2.59$ ). There were two species including CITES Appendix II. Based on the IUCN Red List, there was one species in the Endangered (EN) category, 23 species in the Least Concern (LC) category. There was one species that is protected according to Government Regulation (PP No. 7 of 1999). The 3 species include as protected under the Ministry of Environment and Forestry Regulation (PERMENLHK RI No. P.106, 2018). Monitoring the presence of birds in this area must be carried out regularly.
\end{abstract}

Keywords: Bird Diversity; Conservation Status; Mount Ungaran;

Promasan.

\section{Introduction}

Indonesia as one of the Mega Biodiversity Countries in the world is blessed with Biodiversity and a very high level of ecological uniqueness. Wildlife faunas are important component in an ecosystem, especially forests. They are very essential for the survival of the forest life cycle itself. One of them is bird. Birds are able to play a role in helping to regenerate forest areas naturally such as seed spread, flower pollination and pest attack control. The island of Java is very fertile with the highest population in Southeast Asia. Most of its original forest has been logged for agricultural purposes. With only about $10 \%$ of the habitat remaining and almost all of it montane forest. It seems that the island of Java is no longer able to accommodate the bird species that make up the rich avifauna, not only because the number of birds is decreasing but also due to habitat loss.

Mount Ungaran is one of the dormant volcanoes located in Semarang Regency, Central Java. Administratively, Mount Ungaran is included in two areas, Semarang Regency and Kendal Regency. The condition of unspoiled forests in the Mount Ungaran forest area are good habitat for fauna, such as amphibians, reptiles, birds and mammals. Mount Ungaran is also as habitat for several rare plants including Michelia alba, Hibiscus tiliaceus, Messua ferrea, Cinnamommum cassia, Sapindus rarak, 
Baccaurea racemosa and Dalbergia latifolia (Hidayat et al., 2018). The density of vegetation in the protected forest of Mount Ungaran also varies, from very dense to very rare (Lintang et al., 2017).

Twelve frugivore birds which were visit fig trees in Mount Ungaran have been listed. They were Cabai Bunga-Api (Dicaeum trigonostigma), Cucak Kutilang (Pycnonotus aurigaster), Kadalan Birah (Rhamphococcyx curvirostris), Kadalan Kembang (Zanclostomus malkoha), Merbah Cerucuk (Pycnonotus goiavier), Merbah Corok-Corok (Pycnonotus simplex), Punai Penganten (Treron grieicauda), Serindit Jawa (Loriculus pusillus), Takur Tulung Tumpuk (Megalaima javensis), Takur Tenggeret (Megalaima australis), Uncal Kouran (Macropygia ruficeps), Uncal Loreng (Macropygia unchall) (Priyono et al., 2021). In addition, Mount Ungaran is also as habitat of one of large bird species, Wreathed Hornbill (Rhyticeros undulatus) (Rahayuningsih et al., 2017).

Mount Ungaran is suitable for novice climbers because of its elevation is not extreme. There are several hiking trails to the top of Mount Ungaran, including through the Perantunan Post, Mawar Post, Gedong Songo Post, Promasan Post, and Medini Post. The Promasan hiking trail is one of the most popular route. It's caused by non-extreme terrain and many open areas such as tea plantations. On the other hand, there are also natural forests with tall trees. The ease of this route, makes many climbers go through this route. It influence the presence of animals around this area. In addition, easy access to forest areas makes this route easy for hunters to catch birds.

Study on the diversity and conservation status of birds in this area have not been published. People around Mount Ungaran showed public awarness to preserve nature. So that people really need information about biodiversity, status conservation, and how to preserve it (Rahayuningsih et al., 2020). Therefore, it is very important to conduct a study on bird diversity and its conservation status, so that further policies can be applied regarding tourism regulations around Mount Ungaran, especially on the Promasan hiking trail. This study aims to determine the diversity of bird species and identify the conservation status of bird species on the Promasan hiking trail.

\section{Material and Methode}

\section{Bird species diversity}

This research was carried out in JulyAugust 2020. Indices Ponctuels d'Abondance (IPA), Line Transect, and Point Count methods were conducted to record bird species diversity. Six observation stations were determined as point count. Each station has an interval of 200 meters. Time duration at each station was 20 minutes. Observations were conducted in the morning between $06.00-11.00$ WIB when birds move out of the nest to forage, and continue in the afternoon between 15.00 - 18.00 WIB when birds return to the nest. Data were recorded along the transects for each bird species found including vernacular name and the amount. The research was carried out in the climbing area of the Mount Ungaran start from Promasan base camp (marked as red circle on Figure 1) along the route marked as red arrow on Figure 1. Bird species diversity was determined by the Shanon index.

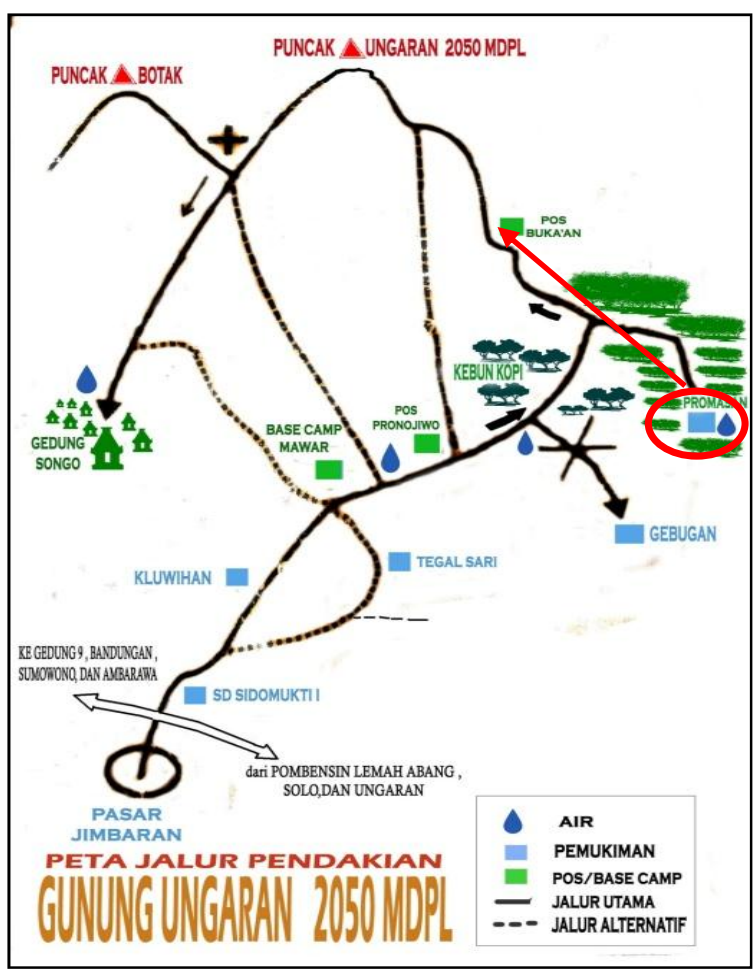

Figure 1. Map of Mount Ungaran Hiking Trail

\section{Conservation Status}

The conservation status of birds was identified based on the IUCN Red List (IUCN, 2021), CITES Appendices I, II, and III (2021), Government Regulation (PP No. 7, 1999) and 
Ministry of Environment and Forestry Regulation (PERMENLHK RI No. P.106, 2018)

\section{Results and Discussion}

\section{Bird species diversity}

There were 24 species of birds belonging to 19 families with 111 individual observed along Promasan hiking trail (Table 1). A number of 78 individuals from 24 species of birds were found at station 1 , while the number of bird at other stations were 30 (station 2), 20 (station 3), 34 (station 4), 17 (station 5) and only 1 individual at station 6.

Table 1. Number of Bird Species on Promasan Hiking Trail

\begin{tabular}{|c|c|c|}
\hline No. & Species & $\sum$ \\
\hline 1. & Pycnonotus aurigaster & 30 \\
\hline 2. & Pericrocotus cinnamomeus & 12 \\
\hline 3. & Collocalia esculenta & 10 \\
\hline 4. & Lonchura leucogastroides & 10 \\
\hline 5. & Passer montanus & 10 \\
\hline 6. & Orthotomus ruficeps & 4 \\
\hline 7. & Geopelia striata & 4 \\
\hline 8. & Zosterops montanus & 4 \\
\hline 9. & Ducula aenea & 3 \\
\hline 10. & Lanius collaris & 3 \\
\hline 11. & $\begin{array}{l}\text { Nectarinia jugularis } \\
\text { (Cinnyris jugularis) }\end{array}$ & 3 \\
\hline 12. & Prionochilus percussus & 2 \\
\hline 13. & Dicaeum trocileum & 2 \\
\hline 14. & Pycnonotus goiavier & 2 \\
\hline 15. & Sitta frontalis & 2 \\
\hline 16. & Alcippe pyrrhoptera & 2 \\
\hline 17. & Spilornis cheela & 1 \\
\hline 18. & Ceyx erithacus (rufidorsus) & 1 \\
\hline 19. & Chloropsis sonnerati & 1 \\
\hline 20. & Centropus sinensis & 1 \\
\hline 21. & $\begin{array}{l}\text { Phaenicophaeus javanicus } \\
\text { Zanclostomus javanicus }\end{array}$ & 1 \\
\hline 22. & Merops leschenaulti & 1 \\
\hline 23. & Picoides canicapillus & 1 \\
\hline 24. & $\begin{array}{l}\text { Pitta guajana } \\
\text { (Hydrornis guajanus) }\end{array}$ & 1 \\
\hline & Total & 111 \\
\hline
\end{tabular}

There are several high and low abundance of species as listed in Table 1. Species that have the highest abundance was Pycnonotus aurigaster. Then followed by Pericrocotus cinnamomeus, Collocalia esculenta and Lonchura leucogastroides.
The abundance of Pycnonotus aurigaster because it belongs to the most widespread bird species in the urban landscape of Java (Kurnia et al., 2021). The bird have capability to adapt to urban habitats. They are accustomed to the presence of humans, including mount climbers who cross the Promasan hiking trail. Pericrocotus cinnamomeus at second rank for the most abundance species in Promasan hiking trail. This bird also adaptive with human presence. Kale et al. (2018) found that Small Minivet (Pericrocoitus cinnamomeus) is one of the birds that build its nest in industrial areas. Lonchura leucogastroides were found at station 1,2,3,4, and 5 because these station contain an abundance of food such as fruits, seeds and insects. Collocalia esculenta were found at station 1,2,3,4,5 where habitat was open and rare large trees.

Species which was low in abundance at point three are Pitta guajana and Ceyx erithacus (rufidorsus). At station four, Centropus sinensis, Chloropsis sonnerati, Merops leschenaulti, and Picoides canicapillus were found. At station five there was a Phaenicophaeus javanicus, and at station six there was Spilornis cheela. The low abundance of these species is due to several factors such as the rate of extinction, long breeding times, their habitat which has become a hiking trail so that the availability of food and nesting places is getting less and less.

Index of bird species diversity in all areas at 6 stations in a value of 2.59794. In accordance to Odum's (1993) criteria, the diversity value $\left(\mathrm{H}^{\prime}\right)$ shows a moderate. The diversity index can also be used to measure community's ability to maintain stable conditions despite disturbances to its community components stability (Indriyanto, 2006).

The existence of varied vegetation that cover the land contributes to the diversity of bird species on the Promasan hiking trail, Mount Ungaran. The presence of birds can also be used as an indicator of environmental quality. In the area of Mount Ungaran, which is still beautiful and has lots of vegetation, it is a comfortable place for bird's habitat. The more diverse the tree species, the more diverse the types of birds that live. The number of tree species is directly proportional to the level of variation of bird species living in that location (Surur et al., 2020). 


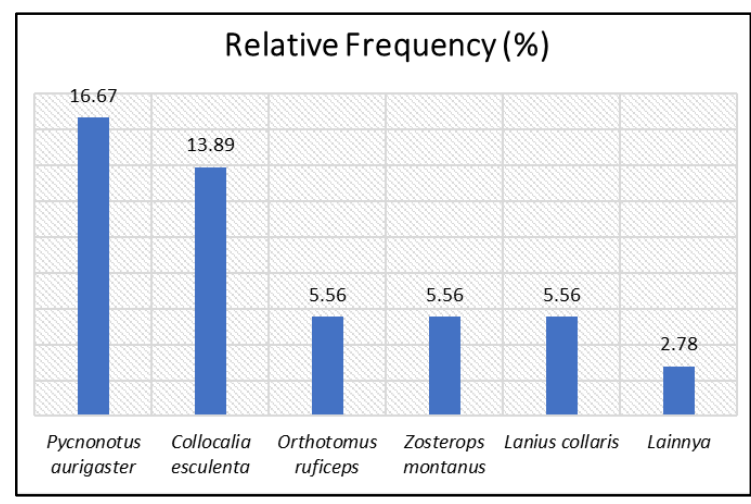

Figure 2. Relative Frequency of birds at Promasan hiking trail.

The distribution of bird species can be seen from the relative frequency value (Figure 2). In this area, the bird species that have the highest relative frequency value and easily found were Sooty-headed Bulbul (Pycnonotus aurigaster) $(\mathrm{FR}=16.67)$ and Glossy Swiftlet (Collocalia esculenta) $(\mathrm{FR}=13.89)$. The distribution of these birds is influenced by the availability of food, feeding behavior, and living behavior. These birds are a type that lives in groups, while Pycnonotus aurigaster were influenced by their omnivorous feeding behavior so they can eat insects and fruit. They can also live up to an altitude of 1600 meters above sea level, preferring open areas such as bushes, forest edges to urban areas (MacKinnon et al., 2010)

\section{Conservation Status of Birds}

Protection status bird species found along the Promasan hiking trail refers to the IUCN Red List, CITES Appendix, Government Regulation (PP No.7 of 1999) and Ministry of Environment and Forestry Regulation (PERMENLHK RI No. P.106, 2018) as shown by Table 2 . There were two types of birds including CITES Appendix II. Based on the IUCN Red List, there was one species in the Endangered (EN) category, 23 species in the Least Concern (LC) category. There was one species include as protected animal according to Government Regulation (PP No.7 of 1999). And 3 species were protected under the Regulation of the Ministry of Environment and Forestry (PERMENLHK RI No. P.106 , 2018).

There are 2 species of birds include as protected animal based on Government Regulation (PP No.7, 1999) concerning the conservation of living natural resources and their ecosystems regulates the protection status of flora and fauna in Indonesia, Crested Serpent Eagle (Spilornis cheela) and Javan Fulvetta (Alcippe pyrrhoptera). These animals are designated as protected animals because based on government records, they have criteria for protected animals such as experiencing population decline, small population size, and having a limited or endemic distribution. Threatened population of Crested Serpent Eagle (Spilornis cheela) was still exist on Promasan hiking trail. The existence of predator bird is important in an ecosystem. In ecosystems, predators occupy positions as top consumers in food webs. If there is a disturbance to the population of predators, it will also disrupt the food web in the ecosystem. In addition, their sensitivity to the environment makes them an indicator of a healthy environment. If environmental conditions are disturbed, it is likely that predator birds will soon become extinct. Based on this role, predator birds are categorized as protected animals (Prawiradilaga et al., 2003).

Javan Fulvetta (Alcippe pyrrhoptera) is endemic of Java, also protected by Governmen Regulation (PP No. 7, 1999). Type of omnivorous bird, have habitats in forests, forest edges, mountains. They spread above an altitude of 1,000 meters above sea level. This species use the three-position space in plants (Partasasmita et al., 2017). Previous studies found the bird on Mount Salak (West Java) and Mount Slamet (Central Java) (Mittermeier et al., 2014).

According to the bird trade protection status, CITES (Convention on International Trade of Endangered Species of Wild Fauna and Flora), there were two species birds which found along the Promasan hiking trail, belong to the Appendix II category. They were Crested Serpent Eagle (Spilornis cheela) and Paok Pancawarna or Banded Pitta (Pitta guajana). Appendix II of CITES is a list of species that are not threatened with extinction, but may be threatened with extinction if trade continues without regulation. Therefore, the trade of this species must be controlled. Research in countries that engaged wildlife trade is necessary to understand the impacts of the trade on bird conservation, and to monitor captive bird populations outside their native ranges (Vall-Llosera \& Su, 2018). 
Table 2. Conservation Status of Bird Species on Promasan Hiking Trail

\begin{tabular}{|c|c|c|c|c|c|c|c|}
\hline \multirow[b]{2}{*}{ No } & \multirow[b]{2}{*}{ Vernacular Name } & \multirow[b]{2}{*}{ Common Name } & \multirow[b]{2}{*}{ Species } & \multirow[b]{2}{*}{ Family } & \multicolumn{3}{|c|}{ Conservation Status } \\
\hline & & & & & CITES & IUCN Category & $\begin{array}{c}\text { National } \\
\text { Protection Status }\end{array}$ \\
\hline 1 & Elang Ular Bido & Crested Serpent Eagle & Spilornis cheela & Accipitridae & II & LC (stable) & Protected by A, B \\
\hline 2 & Udang Merah & Oriental Dwarf Kingfisher & Ceyx erithacus (rufidorsus) & Alcedinidae & & LC (decreasing) & \\
\hline 3 & Wallet Sapi & Glossy Swiftlet & Collocalia esculenta & Apodidae & & LC stable & \\
\hline 4 & Mantenan / Sepah Kecil & Small Minivet & Pericrocotus cinnamomeus & Campepaghidae & & LC (stable) & \\
\hline 5 & Daun Besar & Greater Green Leafbird & Chloropsis sonnerati & Chloropseidae & & EN (decreasing) & Protected by B \\
\hline 6 & Prenjak Abu & Ashy Tailorbird & Orthotomus ruficeps & Cisticolidae & & LC (stable) & \\
\hline 7 & Pergam Hijau & Green Imperial Pigeon & Ducula aenea & Columbidae & & LC (decreasing) & \\
\hline 8 & Perkutut & Zebra Dove, Peaceful Dove & Geopelia striata & Columbidae & & LC (stable) & \\
\hline 9 & But but & Greater Coucal & Centropus sinensis & Cuculidae & & LC (stable) & \\
\hline 10 & Kadalan Kembang & Red-billed Malkoha & $\begin{array}{l}\text { Phaenicophaeus javanicus } \\
\text { (Zanclostomus javanicus) }\end{array}$ & Cuculidae & & LC (decreasing) & \\
\hline 11 & Cabe Punggung Biru & Crimson-breasted Flowerpecker & Prionochilus percussus & Dicaeidae & & LC (stable) & \\
\hline 12 & $\begin{array}{l}\text { Citbang/ Kemade/ Cabe } \\
\text { Jawa }\end{array}$ & Scarlet-headed Flowerpecker & Dicaeum trochileum & Dicaeidae & & LC (stable) & \\
\hline 13 & Cendet & Common Fiscal & Lanius collaris & Laniidae & & LC (increasing) & \\
\hline 14 & Kirik-Kirik Senja & Chestnut-headed Bee-eater & Merops leschenaulti & Meropidae & & LC (increasing) & \\
\hline 15 & Madu Kuning/ Sriganti & Olive-backed Sunbird & $\begin{array}{l}\text { Nectarinia jugularis } \\
\text { (Cinnyris jugularis) }\end{array}$ & Nectarinidae & & LC (stable) & \\
\hline 16 & Caladi Kelabu & Grey-capped Woodpecker & Picoides canicapillus & Picidae & & LC (stable) & \\
\hline 17 & Paok Pancawarna & Banded Pitta & $\begin{array}{l}\text { Pitta guajana } \\
\text { (Hydrornis guajanus) }\end{array}$ & Pittidae & II & LC (decreasing) & Protected by B \\
\hline 18 & Bondol Jawa & Javan Munia & Lonchura leucogastroides & Ploceidae & & LC (stable) & \\
\hline 19 & Burung Gereja & $\begin{array}{l}\text { Europian Tree Sparrow, Tree } \\
\text { Sparrow }\end{array}$ & Passer montanus & Ploceidae & & LC (decreasing) & \\
\hline 20 & Kutilang & Sooty-headed Bulbul & Pycnonotus aurigaster & Pycnonotidae & & LC (decreasing) & \\
\hline 21 & Merbah Cerucuk & Yellow-vented Bulbul & Pycnonotus goiavier & Pycnonotidae & & LC (increasing) & \\
\hline 22 & Rambatan & Velvet-fronted Nuthatch & Sitta frontalis & Sittidae & & LC (decreasing) & \\
\hline 23 & $\begin{array}{l}\text { Flamboyant/ Wergan } \\
\text { jawa/ Brencet wergan }\end{array}$ & Javan Fulvetta & Alcippe pyrrhoptera & Timaliidae & & LC (decreasing) & Protected by A \\
\hline 24 & Pleci Kacamata & Montain White-eye & Zosterops montanus & Zosteropidae & & $\mathrm{LC}$ & \\
\hline
\end{tabular}

A = Government Regulation (PP No.7 of 1999) concerning Preservation of Plants and Animals

B = Ministry of Environment and Forestry Regulation (PERMENLHK RI No. P.106/MENLHK/SETJEN/KUM.1/6/2018) 
Success rate of Crested Serpent Eagle conservation has been conducted through rehabilitation program by planting highstructured trees (Widiasmara \& Arifan, 2020). Land cover in the Promasan area is in the form of vegetation with tall trees and there are also several areas in the form of tea plantations. Crested serpent eagle needs tall trees to perch and build nests, while observing prey below. In addition, the existence of tea plantations as open areas makes it easier for Crested Serpent Eagle to detect their prey and increase hunting success. As Faryanti et al. (2015) found, the Crested Serpent Eagle hunting activity was successfully observed in an open field area. This indicates the importance of having an open area for hunting. The unspoiled forest area on Mount Ungaran is very popular with raptors such as Spilornis chella to make nests. Recent study on the different landscapes preferred by raptors for nesting shows that the Crested Serpent Eagle preferred to site its nest in the natural forest landscape element (Withaningsih et al., 2019).

Other species that include to Appendix II of CITES was Pitta guajana. This species was found near shady and slightly damp rocks, and it was on the move looking for food such as ants, cockroaches, beetles, snails, worms, termites, caterpillars, and other insects. This bird is also included in the list of protected animals based on Ministry of Environment and Forestry Regulation (PERMENLHK RI No. P.106, 2018). This bird is also known by bird traders as "Anis Pancawarna" and is traded because of its special color. Pancawarna means five colors. So the local name of this bird recognized as "panca warna" (five colors) because this bird has five colors of feathers, i.e. black color on the head, yellow on eyebrows, brown on back and wing, white color in the form of wing lines and on the chin; and blue color in on tail (Iskandar et al., 2020).

Based on the IUCN Red List, most of the bird species which is found along the Promasan hiking trail have a low level of extinction threat. Although many bird species are at low risk of extinction, population reduction can still occur due to habitat disturbance by humans. The existence of trees in the forest is very important for animals, especially bird species. Plants in the forest can be a shelter, breeding, or a place to find food.

One species in Endangered (EN) species according IUCN Red List was found in Promasan hiking trail. It was Greater Green Leafbird (Chloropsis sonnerati). It commonly used for bird song contest. A small number of this species found in the market (Iskandar et al., 2020). It's caused by this bird is very rare in nature. Nevertheless, the hunting rate of Chloropsis sonnerati continues to increase. Chloropsis sonnerati is the highest number of individually captured. There were 26 individuals (of 108 indivuduals) were captured from lowland habitats in West Kalimantan (Wicaksono \& Rifqi, 2021). The change of hunting wisdom for Chloropsis sonnerati is also as a factor of the scarcity of these birds in nature. Study about traditional hunting on Chloropsis sonnerati in East Java has been conducted. The hunting season was only conducted in the dry season. They did not do hunting at rainy season, because for the bird mating season. Local people in the past follow this unwritten rule (Kurnianto et al., 2017). However, the increasing of market demand, the increasing number of young hunter, and the emergence of the net method made a difference in hunting wisdom. As a compensation, the population of Chloropsis sonnerati decreasing. Unfortunately, this species is declared as Endangered (EN) by IUCN Red List, but not include in the CITES appendix list. The threatened species uncovered by CITES may be hunted and traded. It would incrase the total number of species exposed to extinction (Gorobets, 2020).

\section{Conclusion}

Based on this research, a total of 24 bird species from 19 families were found along Promasan hiking trail. The diversity of bird species was classified as moderate (Shanon index $=2.59$ ). There were two species including CITES Appendix II. Based on the IUCN Red List, there was one species in the Endangered (EN) category. Another 23 species in the Least Concern (LC) category. There was two species that is protected by Government Regulation (PP No. 7 of 1999). The 3 species are included as protected under the Ministry of Environment and Forestry Regulation (PERMENLHK RI No. P.106, 2018). Monitoring of birds in this area must be carried out regularly. The number of bird populations in nature are dynamics over time, depending on the factors of the intake rate and the output rate of the bird population. The intake factor of bird population are including the rate of 
breeding and migration. Meanwhile, the rate of bird populations output due to loss of habitat and poaching have to be prevented. There must be a match between the CITES appendages and the conservation status on the IUCN Red List.

\section{Acknowledgments}

The researcher would like to express deepest gratitude to all who helped carry out this research.

\section{References}

CITES Appendices I, II, and III, (2021). https://cites.org/sites/default/files/eng/app/ 2021/E-Appendices-2021-06-22.pdf

Faryanti, A., Hernowo, J. B., \& Prasetyo, L. B. (2015). Kesesuaian Habitat Elang Ular Bido (Spilornis cheela LATHAM, 1790) di Koridor Halimun Salak. Jurnal Penelitian Hutan Dan Konservasi Alam, 1790, 151163.

https://doi.org/https://doi.org/10.20886/jph ka.2015.12.2.151-163

Gorobets, A. (2020). Wild fauna conservation: IUCN-CITES match is required. Ecological Indicators, 112, 106091. https://doi.org/https://doi.org/10.1016/j.eco lind.2020.106091

Hidayat, M. S., Dewi, E. R. S., \& Kaswinarni, F. (2018). Inventarisasi Tumbuhan Langka Di Gunung Ungaran Resort Limbangan. Seminar Nasional Sains Dan $\begin{array}{lll}\text { Entrepreneurship } \quad V, & 9 .\end{array}$ http://prosiding.upgris.ac.id/index.php/sns ev/snse2018/paper/viewFile/2979/2913

Peraturan Pemerintah Republik Indonesia Nomor 7 Tahun 1999 Tentang Pengawetan Jenis Tumbuhan dan Satwa, 26 (1999). https://peraturan.bpk.go.id/Home/Details/5 4143/pp-no-7-tahun-1999

Indriyanto. (2006). Ekologi Hutan. Bumi aksara, Jakarta. ISBN: 9789795262534, pp: 209.

Iskandar, J., Iskandar, B. S., Mulyanto, D., Alfian, R. L., \& Partasasmita, R. (2020).
Traditional ecological knowledge of the bird traders on bird species bird naming, and bird market chain: A case study in bird market pasty Yogyakarta, Indonesia. Biodiversitas, 21(6), 2586-2602. https://doi.org/10.13057/biodiv/d210631

IUCN. (2021). The IUCN Red List Threatened Species. https://www.iucnredlist.org/

Kale, M., Ferrante, M., Dudhe, N., Kasambe, R., Trukhanova, I. S., Ivanova, T., Bhattacharya, P., \& Lövei, G. L. (2018). Nestedness of bird assemblages along an urbanisation gradient in Central India. Journal of Urban Ecology, 4(1), 1-8. https://doi.org/10.1093/jue/juy017

Kurnia, I., Arief, H., Mardiastuti, A., \& Hermawan, R. (2021). The potential of bird diversity in the urban landscape for birdwatching in Java, Indonesia. Biodiversitas, 22(4), 1701-1711. https://doi.org/10.13057/biodiv/d220413

Kurnianto, A. S., Arifianto, A., Narjianto, E., Firdaus, A. S., Iqbal, M., \& Kurniawan, N. (2017). The traditional hunting on Greater Green Leafbird (Chloropsis sonnerati) in East Java: A vulnerable situation for vulnerable bird. Journal of Biological Researches, 23(1), 13-19. https://doi.org/10.23869/bphjbr.23.1.20173

Lintang, N. C., Sanjoto, T., Tjahjono, H., \& Artikel, I. (2017). Kajian Kerapatan Vegetasi Hutan Lindung Gunung Ungaran Jawa Tengah Tahun 2016 Menggunakan Metode Indeks Vegetasi. Geo-Image, 6(1), 1-7. https://doi.org/10.15294/geoimage.v6i1.15 243

MacKinnon, J., Philips, K., \& Van Balen, B. (2010). Panduan Lapangan Burungburung di Sumatera, Jawa, Bali dan Kalimantan. LIPI.

PERMENLHK RI No. P.106, Kementrian Lingkungan Hidup dan Kehutanan 30 (2018). http://ksdae.menlhk.go.id/assets/news/pera 


$$
\text { turan/P.106-2018_JENIS_TSL_.pdf }
$$

Mittermeier, J. C., Oliveros, C. H., Haryoko, T., Irham, M., \& Moyle, R. G. (2014). An avifaunal survey of three Javan volcanoes-Gn Salak , Gn Slamet and the Ijen highlands. BirdingASIA, 22, 91-100. https://www.researchgate.net/profile/JohnMittermeier/publication/274387607_An_a vifaunal_survey_of_three_Javan_volcanoe S--

Gn_Salak_Gn_Slamet_and_the_Ijen_highl ands/links/5566327f08aeccd77735a0c9/A n-avifaunal-survey-of-three-Javanvolcanoes--Gn-Salak-Gn-Sl

Odum, E. P. (1993). Dasar-dasar Ekologi (3rd ed.). UGM Press, Yogyakarta. ISBN: 9794202843, pp: 697.

Partasasmita, R., Atsaury, Z. I. A., \& Husodo, T. (2017). The use of forest canopy by various bird species in tropical forest montana zone, the Nature Reserve of Mount Tilu, West Java, Indonesia. Biodiversitas, 18(2), 453457.

https://doi.org/10.13057/biodiv/d180202

Priyono, B., Abdullah, M., Febriyanto, M. N. F., Bodijantoro, P. M. H., \& Purwantoyo, E. (2021). Fig visitor's behaviour in Ungaran mountain, Indonesia. Journal of Physics: Conference Series, 1918(5), 052044. https://doi.org/10.1088/1742$6596 / 1918 / 5 / 052044$

Rahayuningsih, M., Priyono, A. B. P., Widjanarko, A., \& Ayu, G. (2020). The Study of community knowledge on biodiversity in Mount Ungaran. Journal of Physics: Conference Series, 1567(3). https://doi.org/10.1088/17426596/1567/3/032045

Rahayuningsih, Margareta, Kartijono, N. E., \& Retnoningsih, A. (2017). Short communication: The nest characteristics of wreathed hornbill (Rhyticeros undulatus) in Mount Ungaran, Central Java, Indonesia. Biodiversitas, 18(3), 1130-1134. https://doi.org/10.13057/biodiv/d180334
Surur, A., A'tourrohman, M., \& Purnamaningrum, A. (2020). Hubungan Keanekaragaman Jenis Burung dan Komposisi Pohon di Kampus 2 Uin Walisongo Semarang The Relationship of Diversity Type of Birds and Tree Composition In Campus 2 Uin Walisongo Semarang. Jambura Edu Biosfer Journal, 2(2), 57-64. https://doi.org/https://doi.org/10.34312/jeb $\mathrm{j}$

Vall-Llosera, M., \& Su, S. (2018). Trends and characteristics of imports of live CITESlisted bird species into Japan. International Journal of Avian Science, 161(3), 590-604. https://doi.org/https://doi.org/10.1111/ibi.1 2653

Wicaksono, G., \& Rifqi, M. A. (2021). Diversity and Threat Hunting of the Birds in the Labian-Leboyan Corridor West Kalimantan. 1(3), 179-185. http://ejournal.unas.ac.id/index.php/bio/article/vie w/66

Widiasmara, R. P., \& Arifan, F. (2020). Konservasi Elang Bido Di Taman Kehati Pupuk Kujang. O1(1), 15-26. https://ejournal2.undip.ac.id/index.php/pen tana/article/view/11601

Withaningsih, S., Parikesit, Iskandar, J., \& Prawiradilaga, D. M. (2019). Conservation and management strategies for the sustainability of raptors in a humanmodified landscape. International Journal of Conservation Science, 10(4), 749-762. http://ijcs.ro/public/IJCS-19-

67_Withaningsih.pdf 